Katarina Horvat-Levaj

Institut za povijest umjetnosti, Zagreb

\section{Relja Seferović}

Zavod za povijesne znanosti HAZU, Dubrovnik

Izvorni znanstveni rad / Original scientific paper

UDK / UDC: 728.3.034.5(497.5 Dubrovnik)

4. 11. 2013.
Palača Luccari na Pustijerni: obnova dubrovačke stambene arhitekture nakon potresa 1667. godine $u$ svjetlu novih arhivskih istraživanja

Ključne riječi: Dubrovnik, Pustijerna, vlasteoska obitelj Luccari, palača, renesansa, obnova nakon potresa 1667. godine Key words: Dubroonik, Pustijerna, Luccari family palace, Renaissance, restoration after the 1667 earthquake

Palača u Bandurevoj ulici 3 na Pustijerni, tradicionalno pripisivana vlasteoskoj obitelji Kaboga, pripada među najkvalitetnija ostvarenja renesansne stambene arhitekture u Dubrovniku, te je kao takva bila građevinski i restauratorski istražena 1980-ih godina. Novootkriveni dokumenti o njezinoj obnovi nakon potresa 1667. godine u Državnom arhivu Dubrovnika ne samo da su pokazali nove pojedinosti o povijesti gradnje same palače nego su otkrili da je u prošlosti pripadala vlasteoskoj obitelji Luccari (čiji grb, krivo tumačen kao Kabogin, obilježava njezine pročelne portale). Troškovnik obnove, vođene od 1670. do 1674. godine, donoseći imena majstora, ujedno svjedoči da je u kontekstu obnove dubrovačke stambene arhitekture neposredno nakon potresa, palača Luccari, u stanovitim elementima, poput formiranja otvorenog prostora s paviljonom, imala i svojevrsno prototipsko značenje.

Istraživanje stambene arhitekture predstavlja granu povijesne arhitekture koja se najmanje može osloniti na podatke iz arhivskih izvora. Čak i kada je u pitanju grad tako promišljene društveno-političke organizacije i tako visoke urbanističke kvalitete kao što je Dubrovnik, dokumenti o vlasnicima i graditeljima rezidencija u razdoblju od romanike do baroka, ako se i jave, pisani su tako da u tek rijetkim slučajevima omogućuju povezivanje podataka $\mathrm{s}$ konkretnim građevinama. Tako nezahvalna situacija u pogledu pisanih izvora zahtijeva od istraživača povijesne stambene arhitekture, kao svojevrsnu nadoknadu, vrhunsko umijeće u čitanju materijalnih izvora kako bi se mogli izvesti relevantni zaključci o dataciji, atribuciji i valorizaciji arhitektonskih spomenika. Navedene osobine krase i slavljenicu ovoga Zbornika, profesoricu i doktoricu Nadu Grujić. Posvetivši cijeli svoj radni vijek istraživanju gotičke i renesansne stambene arhitekture, Nada Grujić zaslužna je ne samo za znalačku obradu dubrovačkih ljetnikovaca i palača nego je njezinom zaslugom taj vrijedan segment hrvatske baštine dobio i odgovarajuće mjesto u europskoj povijesti arhitekture. Nakon brojnih monografskih studija o ladanjskoj arhitekturi dubrovačkog područja, te nekoliko zaokruženih studija i knjiga o toj tematici, ${ }^{1}$ na redu je i jednaki sintezni prikaz gotičkih i renesansnih palača unutar dubrovačkih zidina. ${ }^{2}$

U tom kontekstu Nada Grujić posvetila je mnogo pažnje i jednoj od najkvalitetnijih renesansnih palača u gradu, Kaboginoj (Kabužićevoj) u Bandurevoj ulici 3 na Pustijerni. 


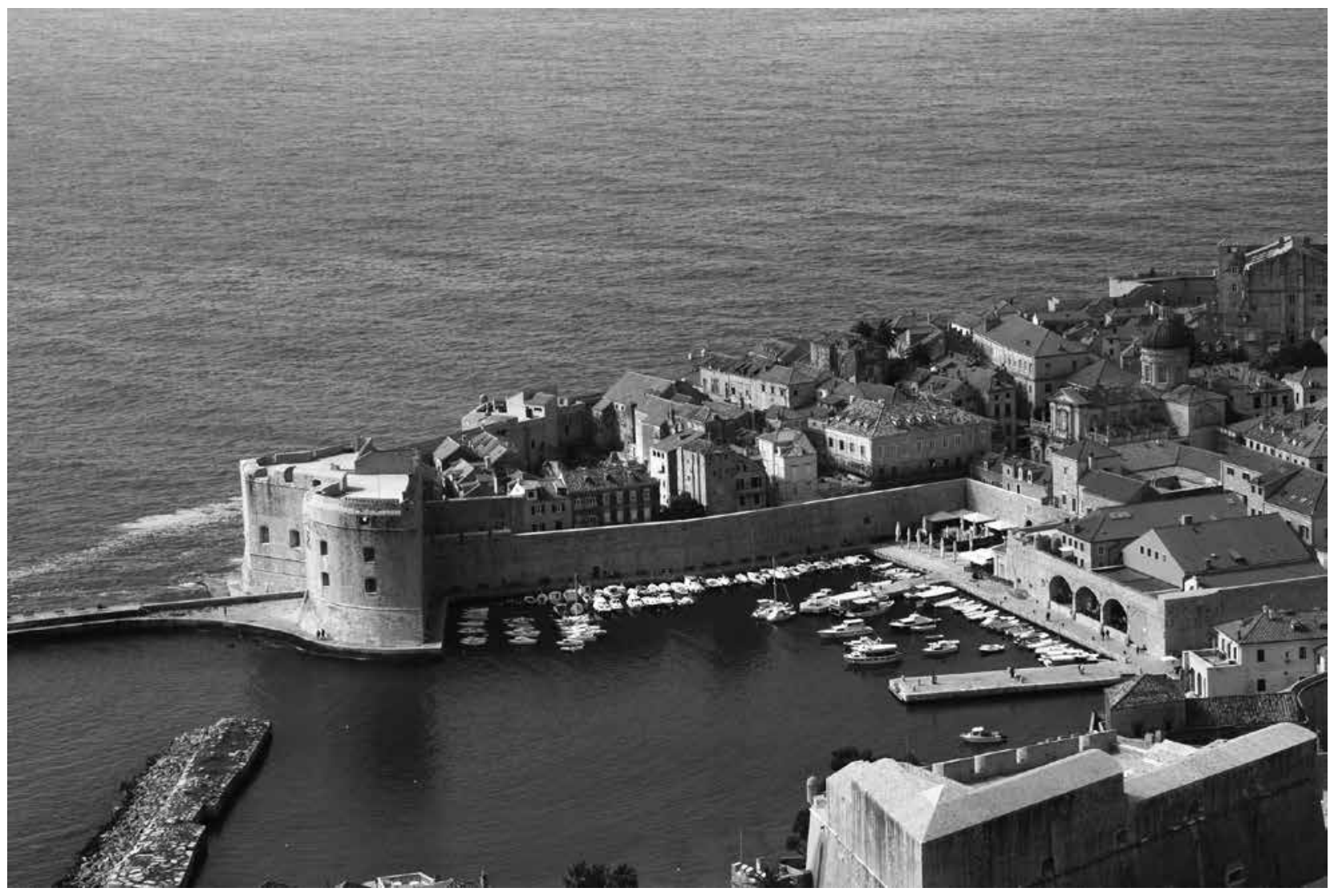

Dubrovnik, Pustijerna (foto: K. Horvat-Levaj) / Dubrovnik, Pustijerna

Nakon što je palača istražena u okviru plana za obnovu Pustijerne (1983.-1984.), ${ }^{3}$ vodila je njezina restauratorska istraživanja (1989.). ${ }^{4}$ Razlučivši faze gradnje, od najstarije romaničke (od koje je ostala samo monofora na začelju), preko dominantne renesansne iz 16. stoljeća (kada se oblikuje prostorna organizacija i pročelje trokatne palače), do obnove nakon oštećenja u potresu 1667. godine, interpretirala je ujedno palaču u okviru vlasteoskih vlasničkih odnosa tijekom srednjeg vijeka i renesanse na Pustijerni (2001.). ${ }^{5}$

Prema riječima Nade Grujić, renesansna palača u Bandurevoj ulici 3 »ističe se položajem, prostornim konceptom i kvalitetom izvedbe «. ${ }^{6}$ Posebnost položaja palače očituje se, osim blizine nekadašnjeg samostan sv. Tome (srušenog u potresu 1667.), činjenicom da sotoportikom premošćuje glavnu komunikaciju toga dijela grada - ulicu Od Pustijerne. ${ }^{7}$ Iznimnost renesansne prostorne koncepcije proizlazi pak iz reprezentativnog tretmana dviju nadsvođenih prostorija prizemlja - ulaznog predvorja i magazina - obiju rastvorenih pročelnim portalima s grbovima vlasnika, te iz karakteristične dvodijelne dispozicije katova - niskoga prvog, višega drugog i najvišega trećeg kata - s dvoranom i bočnom prostorijom, kao i iz rješenja stubišta koje se nakon smještaja uz bočni i začelni zid predvorja u prizemlju i međukatu, od prvog kata naviše prebacuje u prostor kanala (klončine) između dvaju nizova bloka. I na kraju kvaliteta izvedbe vidljiva je jednako na vanjštini s prozorima linearno profiliranih okvira i vješto klesanim kamenim portalima, od kojih glavni ima lunetu bogate biljne dekoracije, kao i u unutrašnjosti sa stubištem ograđenim renesansnom balustradom te s bogato ukrašenim kamenim pilom, kao i brojnim portalima na spojevima između prostorija. Svoju analizu povijesti izgradnje renesansne palače Nada Grujić zaključila je u konzervatorskoj studiji 1989. godine riječima: Usprkos provedenim arhivskim istraživanjima, jedini pouzdani podatak o vlasnicima u 16. stoljeću, ostaju grbovi na oba portala palače. $\aleph^{8}$

Jesu li isti vlasnici zadržali palaču u posjedu i nakon velikih promjena koje je prouzročio potres 1667 . godine, $\mathrm{i}$ kako se odvijala obnova palače, donijela su nova arhivska istraživanja koja smo proveli u Državnom arhivu u Dubrovniku. ${ }^{9}$ Štoviše, iznenađujuće opsežna dokumentacija izazvana, kako je to često bivalo u prošlosti, vlasničkim prijeporima, bacila je novo svjetlo i na renesansnu fazu palače u Bandurevoj ulici 3.

Iz spisa u fondu Diversa de foris doznajemo ${ }^{10}$ naime da su 17. studenoga 1670. braća Matej Šimunov Ghetaldi (Ge- 


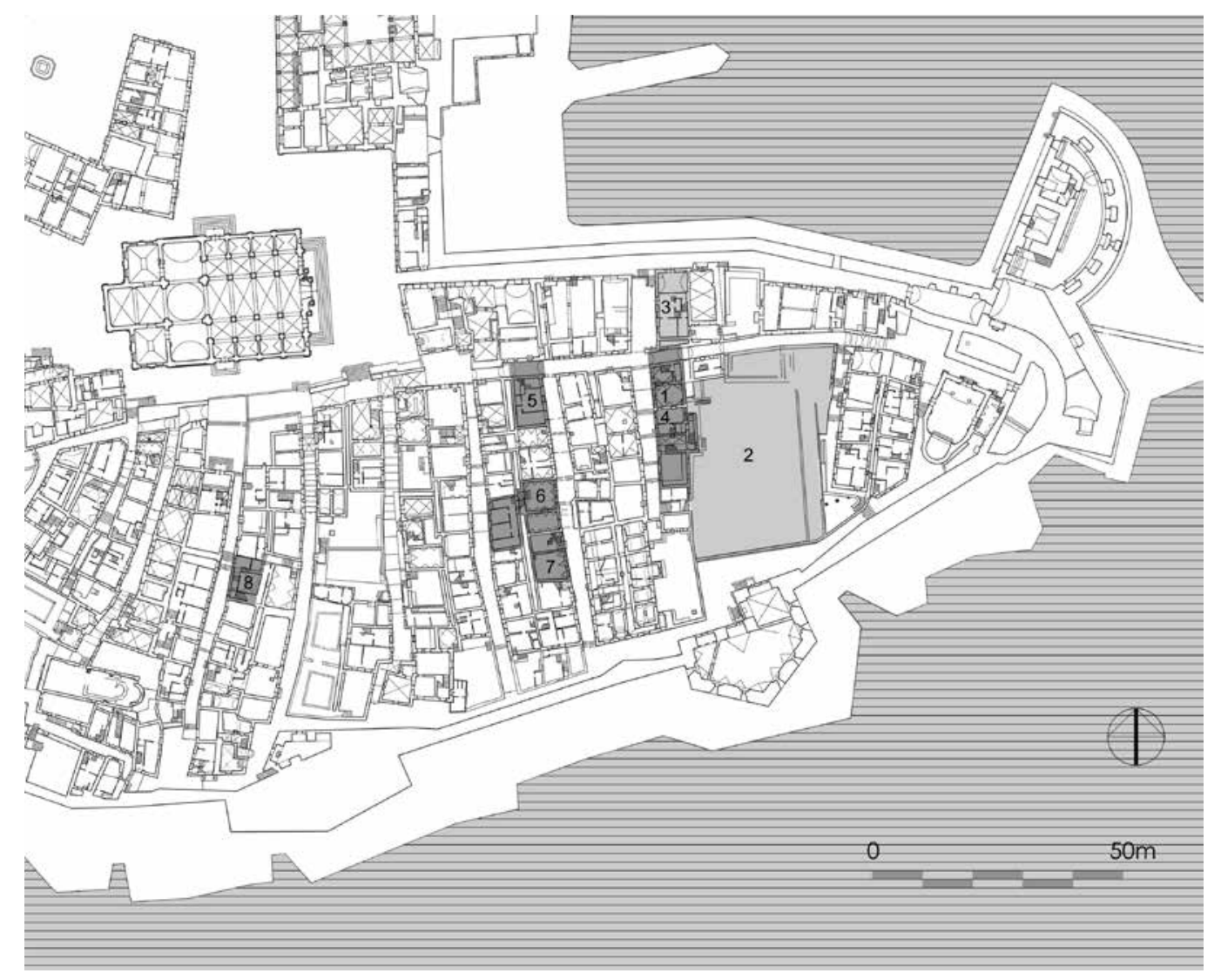

Pustijerna, tlocrt na razini prizemlja s označenom palačom Luccari u Bandurevoj ulici 3 (grafička obrada: I. Tenšek) / Pustijerna, ground floor plan, marking the Luccari Palace in 3 Bandureva St (graphic design I. Tenšek)

taldić), zaređen kao brat Alfonso u samostanu sv. Jakova, ${ }^{11} \mathrm{i}$ Franjo Šimunov Ghetaldi, od svojega ujaka, pokojnog plemića Franje Luccarija, ${ }^{12}$ naslijedili veliku kuću smještenu u ulici Mandaljenić na Pustijerni (današnja Bandureva ulica). Oni tu kuću ustupaju svom stricu, plemiću Ivanu Matejevu Ghetaldiju pod uvjetom da je on mora »obnoviti, popraviti i izvršiti sve potrebne zahvate kako bi postala useljiva «. Kada to izvrši, smije sa svojim nasljednicima uživati kuću, »kao da je njegova «, tijekom pet godina, a nakon toga nasljednici kuće, braća Matej i Franjo sa svojim potomcima, smiju preuzeti navedenu kuću. Zauzvrat moraju obnovitelju kuće Ivanu Matejevu platiti onoliko koliko je on potrošio za obnovu kuće. Dana 4. ožujka 1684., sin i nasljednik navedenog Ivana Matejeva, Matej Ivanov Ghetaldi, odrekao se kuće u korist plemića Franje Žigmundova Gradija (Gradića) ${ }^{13}$ koji mu je za to isplatio 584 dukata, koliko je pokojni plemić Ivan Matejev Ghetaldi potrošio za obnovu. Franjo Žigmundov se potom 29. studenoga 1685. odrekao kuće u korist Marina Junija Gradija koji mu je platio isti iznos obnove - 584 dukata. Dana 15. svibnja 1687. plemić Franjo Šimunov Ghetaldi, nasljednik kuće, kojemu je po prvotnom spisu pripadalo pravo otkupa navedene kuće, ustupio je pravo Marinu Juniju Gradiju da za (dodatnu) obnovu kuće smije potrošiti »za korisnu i neophodnu opremu« (pokućstvo, namještaj) do 15 dukata. Dana 17. svibnja 1688. »dolazeći u Kancelariju i vidjevši račune izvršenih radova« od 112 dukata i 28 groša, Franjo Šimunov Ghetaldi ih je odobrio, jednako kao i prethodni trošak od 584 dukata. Da bi se moglo legalno izvršiti ove zamršene transakcije koje rječito govore o teškim vremenima nakon potresa kada je imati (u potresu oštećenu) kuću bilo više teret nego dobitak koji se lako ustupao drugima, bilo je potrebno izraditi i troškovnik njezine obnove, koji je 3. ožujka 1684. pod prisegom potvrdio Matej Ivanov Ghetaldi. ${ }^{14}$

I upravo zahvaljujući preciznim opisima u spomenutom troškovniku možemo navedene dokumente vezane uz palaču Luccari povezati s palačom u Bandurevoj 3, zvanoj Kaboga. Naime, u okviru brojnih zahvata, vođenih od rujna 1670. do ožujka 1674. godine jasno se navodi ne samo otvaranje prozora »sa strane Sv. Tome«, što bi se moglo odnositi i na susjednu renesansnu palaču u nizu (Bandureva 5, 7), obilježenu grbovima Sorga (Sorkočevića), nego troškovnik uključuje i postavljanje prozorskih krila na fasadi prema Ponti (luci). Tu fasadu u navedenom bloku ima samo palača na adresi Bandureva 3, jer je srednjovjekovna kuća-kula u nizu sub varicos sjeverno od nje bila srušena u potresu, ${ }^{15}$ te 


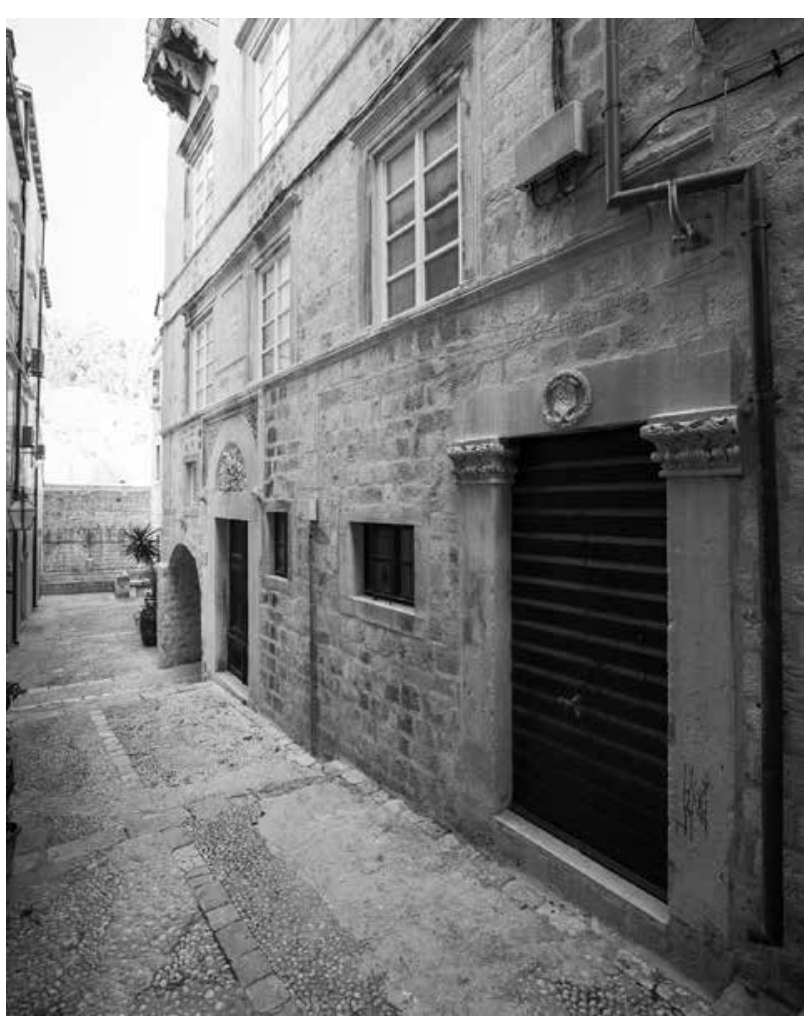

Palača Luccari, glavno pročelje (foto: P. Mofardin) / Luccari Palace, main front

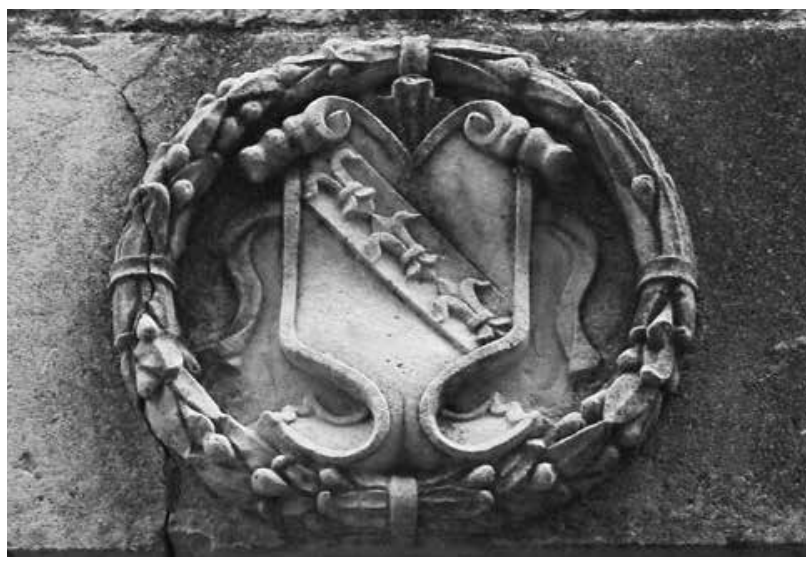

Grb Luccarija na nadvratniku portala magazina (foto: K. HorvatLevaj) / Luccari coat of arms above the storage room portal

se na njezinu mjestu sve do kraja 18. stoljeća nalazio prazan prostor. ${ }^{16}$ Iz navedenoga bi se moglo pretpostaviti kako je između 16. stoljeća, kada se klešu grbovi na pročelnim portalima palače, i druge polovine 17. stoljeća, kada dokumenti spominju Luccarije, došlo do promjene vlasništva da pomnijim uvidom u same grbove nismo došli do zaključka da na palači u Bandurevoj 3 nisu isklesani grbovi obitelji Kaboga, nego grbovi obitelji Luccari. U okviru štita s dijago-

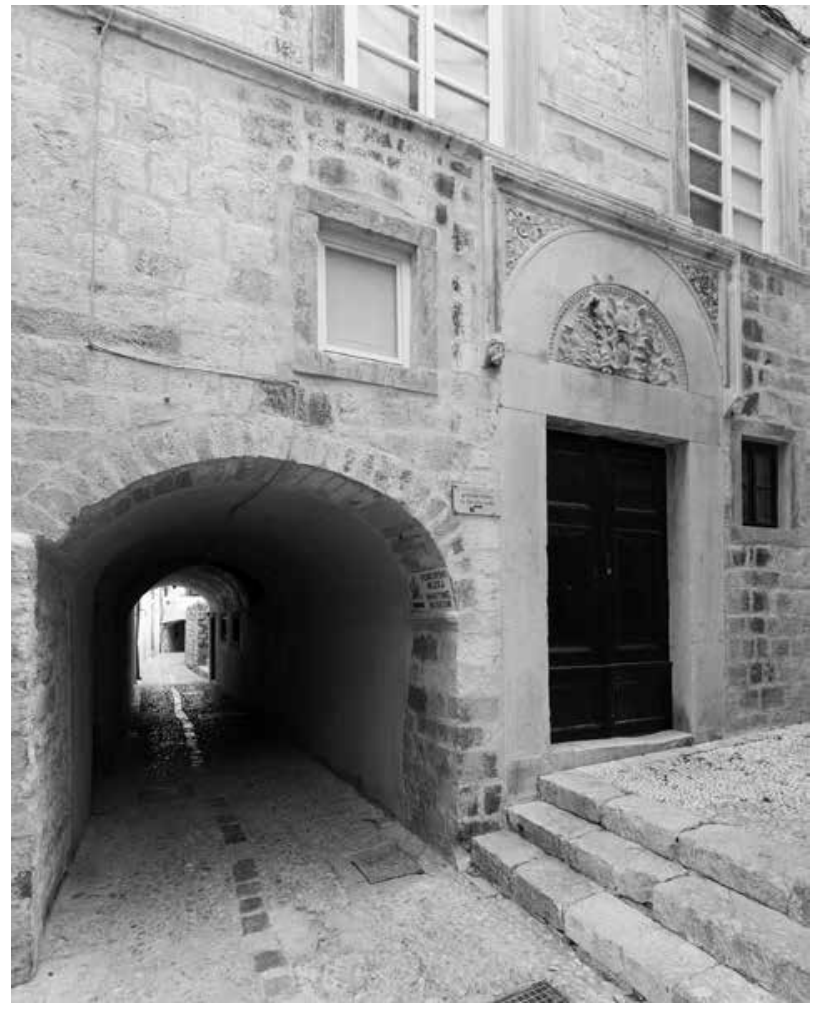

Glavni portal i sotoportik preko Ulice od Pustijerne (foto: P. Mofardin) / Main portal and sottoportico across Pustijerna street

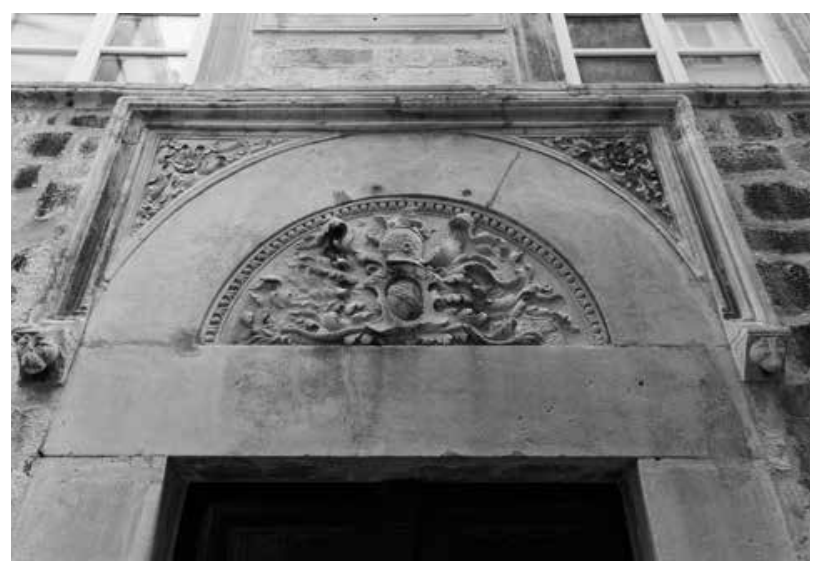

Grb Luccarija u luneti glavnog portala (foto: K. Horvat-Levaj) / Luccari coat of arms in the main portal lunette

nalnom trakom ukrašenom trima ljiljanima, razlika između grbova tih dviju porodica očituje se u orijentaciji ljiljana: kada su položeni u osi trake (kao što je na palači), riječ je o Luccarijima, a kada su postavljeni poprečno na os trake, riječje o grbu Kaboga. Tko je prvi pogriješio prepoznavši grb Luccarija kao Kabogin, teško je reći, no palača u Bandurevoj 3 zadržala se u stručnoj literaturi kao Kabogina. ${ }^{17}$ Korekcija ove greške imat će daljnje posljedice i na, od Nade Grujić 

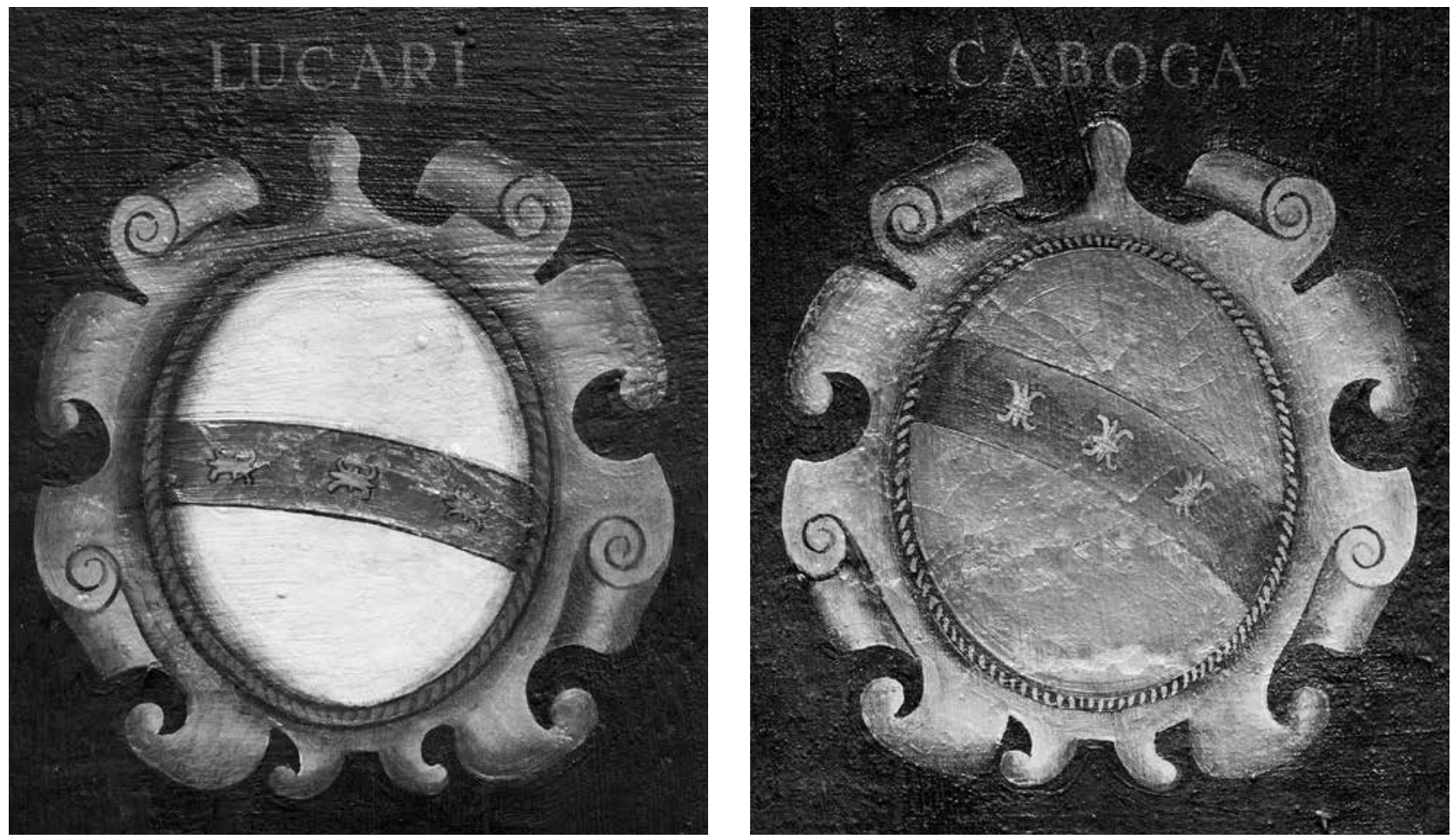

Grbovi Luccarija i Kaboga, Dubrovački muzeji - Knežev dvor / Luccari and Kaboga coats of arms, Dubrovnik museums - Rector's Palace

započeto, istraživanje vlasničkih odnosa na Pustijerni, no vratimo se daljnjim novostima koje donosi troškovnik obnove renesansne palače Luccari nakon potresa.

Iz troškovnika je vidljivo da četverogodišnja obnova počinje u rujnu 1670. obaranjem kuće - per sbater la casa - što se očito odnosi na njezine ruševne (gornje) dijelove, nakon čega slijedi nabava materijala (kupe, vapno, pijesak, okovi, drvena građa) i postavljanje skela, uključivo i konope za vučenje velikih klesanih elemenata - per due corde per tirar li scarpelli grossi, ali i za spuštanje (tj. uklanjanje) velikih (oštećenih) klesanih elemenata iz kuće - per calar i travi scarpelli et altre cose grossi. Potkraj godine slijede isplate majstoru Matku Štrbiniću, zidaru Nikoli s pomoćnicima i zidaru Bartolomeju Andrijinu Đangradoviću, te stolaru Spiculi i drugim majstorima. Početkom 1671. godine spominje se obnova vrata u saloči (salocia), tj. njihovo učvršćivanje metalnim kopčama i čavlima, kao i postavljanje brave na glavna vrata, da bi u ožujku bio isplaćen majstor Grankošić za kupe, a u svibnju 1672. obnova je došla do kuhinje u začelnom potkrovnom dijelu kuće gdje se namještaju prozori i popravlja krov. U okviru tih zahvata »obara se kut pričvršćen za kuću koji prijeti rušenjem «, te se "podiže i postavlja na mjesto« začelni prozor »na strani Sv. Tome«. U rujnu iste godine postavljaju se okovi na dva prozora, jedan u sobi i drugi »ispred sobe u saloči«, potom u listopadu stolar Sausović namješta paviljon, u studenom Vicković iz Kotora radi »luk male sobice» i postavljaju se prozorski kapci "na fasadi prema Ponti« per porte della finestra alla facciata di Ponta - a u prosincu je isplaćen stolar Stochetto za namještanje paviljona - per accomodar padiglione. U siječnju 1673. plaća se majstor da napravi luk iznad velikog prozora, u veljači se postavljaju ploče na vanjska vrata - per una piastra posta alle porte di fora, per altra piastra posta alla bocca di scarpello - te se izrađuju dvije velike ukrasne ploče za vrata »solarija - per due sglobi grandi per le porte del solaro - za koju se nabavljaju i grede (vjerojatno za pergolu) - per 4 spranghe per il solaro. Također se uklanjaju ruševine iz dvorane (sala) i isplaćuju se zidari da naprave stubište i obijele kuću. Idući mjesec obrađuje se tupina za svod, a u lipnju su se naručile tri drvene ploče da se "zatvori otvor u saloči« te se isplaćuje stolar Juraj Nijemac. U siječnju 1674. stolar Nijemac i zidar isplaćeni su za »volte«, u saloči se namješta pilo i spojne grede, potom je slijedila izrada stubišta u potkrovlju, zidar Stjepan je ponovno izbijelio mrlje i otklonio nedostatke, u ožujku je plaćen zvekir, te je na kraju uslijedila isplata već spomenutom stolaru Nijemcu za izradu ormara i prozora u kuhinji. Nakon ove obnove koju je proveo, kao što je spomenuto, Ivan Matejev Ghetaldi, potrošivši 584 dukata, uslijedila je, prema izvorima, 1687. do 1688. godine još jedna dodatna obnova na koju je Marin Junijev Gradi potrošio 112 dukata (no nije specificirano na što).

Navedeni podaci iz troškovnika zorno nadopunjuju spoznaje o građevinskim intervencijama na palači Luccari 

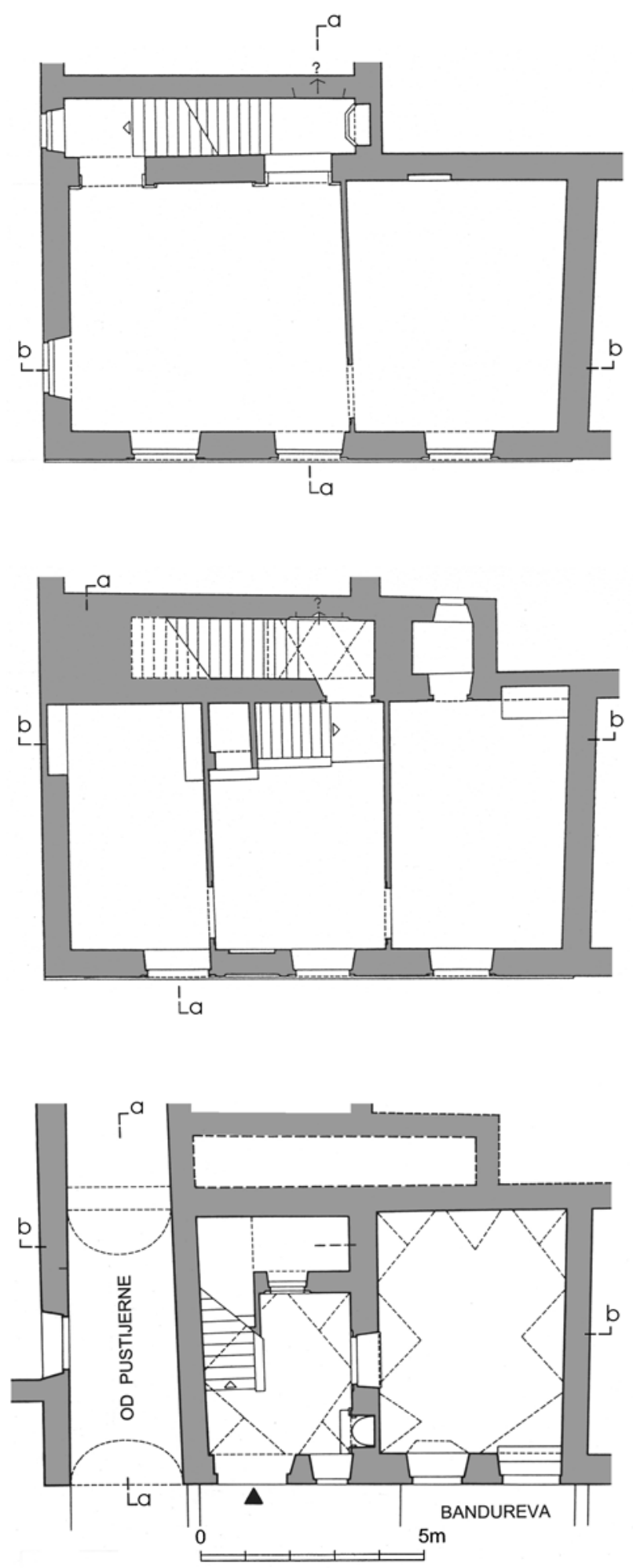

Palača Luccari, tlocrt prizemlja, prvog i drugog kata (grafička obrada: I. Tenšek) / Luccari Palace, plan of ground floor, first floor and second floor (graphic design I. Tenšek)

i njezinu okolnom prostoru nakon potresa 1667. godine, do kojih se došlo tijekom istraživanja (1983.-1984.), ${ }^{18}$ arheoloških iskopavanja (1987. $)^{19} \mathrm{i}$ restauratorskih sondiranja (1989.). ${ }^{20}$ Osim što su oštetila palaču, razaranja u potresu donijela su naime velike urbanističke promjene u tom dijelu grada: nekada urasla s tri strane u blok (dvostruki niz), tako da joj je bilo slobodno samo zapadno ulično pročelje, palača se sada oslobađa, kako je već spomenuto, sa sjeverne bočne strane gdje pada kuća-kula u nizu sub varicos, te djelomično i s istočne začelne strane ${ }^{21}$ gdje u potresu nestaju dva bloka kuća i ulica između njih. ${ }^{22}$ Spomenute promjene odrazile su se i na unutrašnju organizaciju palače, ali i na oblikovanje njezine vanjštine. Dok prizemlje i međukat zadržavaju renesansni raspored, već na prvom katu prijašnja asimetrična dvodijelna podjela, $s$ većom saločom i manjom bočnom prostorijom, usitnjuje se tako što postaje trodijelna, iako i dalje središnjoj prostoriji glavni biljeg daje efektna renesansna balustrada stubišta. Samo pak kameno stubište, zadržavajući raniju poziciju i organizaciju, prema podacima iz troškovnika, biva iznova podignuto nakon potresa. Na drugom katu ostaje raniji dvodijelni raspored, ali uz izmjenu formata saloče ${ }^{23}$ koja postaje glavna dvorana, čijem se uređenju u obnovi pridavalo mnogo pozornosti, o čemu, uz pisane podatke, govore i kameni lučni portali stubišta, izvedeni možda tijekom druge obnove (budući da se u troškovniku ne spominju). Izvorno najreprezentativniji treći kat $s$ velikom dvoranom (salom) morao je pak zbog ruševnog stanja biti snižen, čime su uklonjeni nekadašnji dominantni otvori na pročelju (vjerojatno središnja polifora i bočne monofore - balkonate), ustupivši mjesto pravokutnim otvorima - središnjem prozoru i bočnim balkonskim vratima - o čijoj izvedbi podatke također čitamo u troškovniku obnove. Izgledom usklađeni s pravokutnim renesansnim prozorima na donjim katovima, ali od njih manji, stanovito sjećanje na nekadašnju reprezentativnost piano nobile nadoknađuju oblikovanjem balkona koji koriste kamene konzole renesansnih balkonata. Istodobno, probijanjem bočnih te obnavljanjem začelnih prozora na dva gornja kata, spomenutim u troškovniku obnove, valorizira se promijenjena urbanistička situacija, uz poboljšanje insolacije i vizura iz unutrašnjeg prostora palače. Taj novi senzibilitet kulminira u oblikovanju vanjskoga slobodnog prostora "solarija« i paviljona. Iako nije isključeno da je bila riječ o krovnoj loži, kakvih i danas ima na Pustijerni (Pobijana 10), s obzirom na podatak iz troškovnika o izradi vanjskih vrata solarija te o narudžbi greda, vjerojatno za pergolu, vjerojatnije je da se navedeni podaci odnose na uređenje vrta na mjestu susjednih srušenih kuća - sjeverne u nizu sub varicos uz luku (današnja Bandureva 1) ili istočno na lokalitetu Sv. Tome, gdje se nakon potresa formira veliki vrt s ortogonalno raspoređenim šetnicama, za koji se dosada smatralo da je pripadao samo susjednoj palači Sorkočević u Bandurevoj 5, 7. ${ }^{24}$

Prema tome, iako sama gradnja svjedoči a izvori potvrđuju da je nakon potresa 1667. godine renesansna palača Luccari samo popravljena, bez radikalno novih baroknih stilskih zahvata, ona je ipak, zajedno sa svojom novopro- 

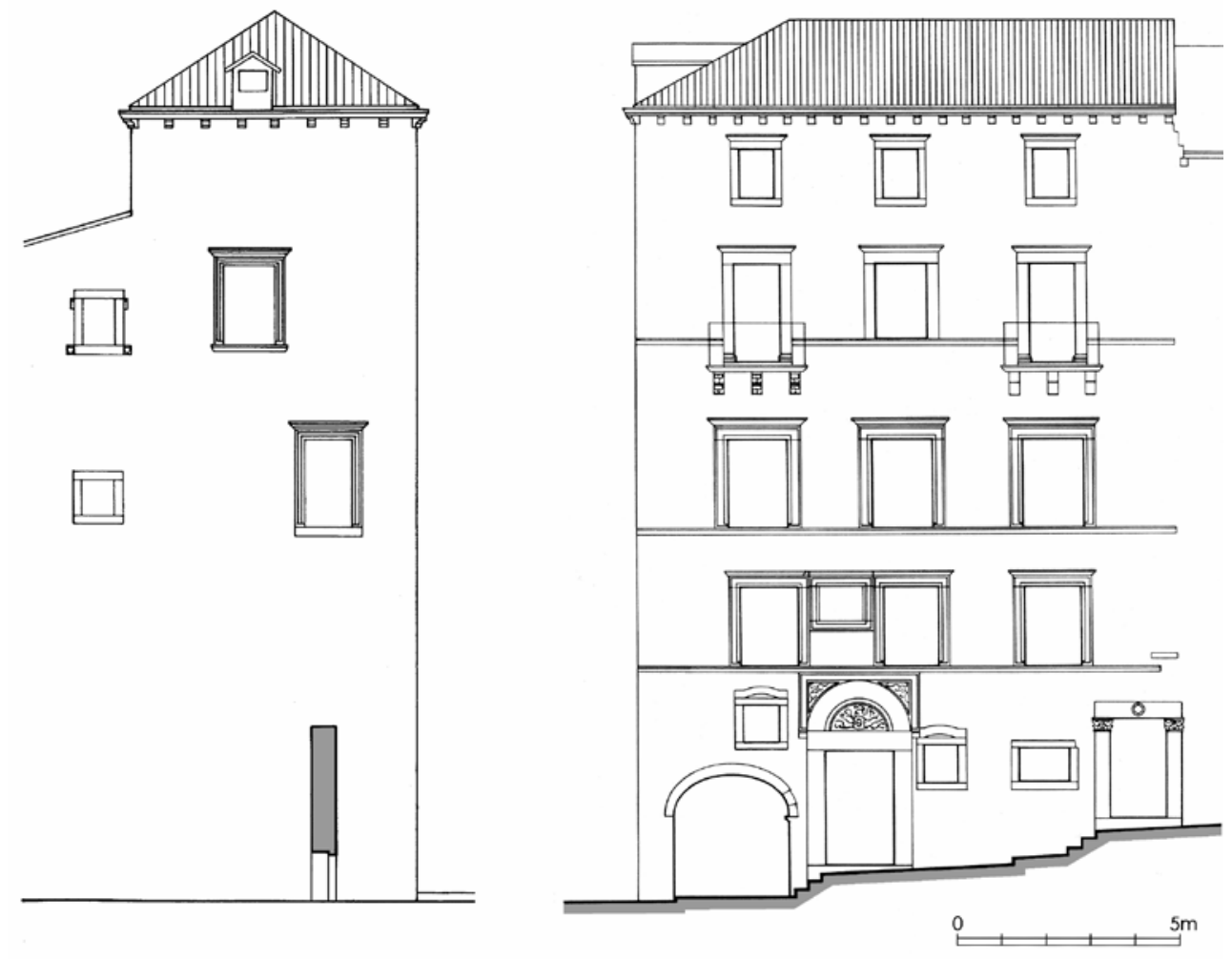

Palača Luccari, sjeverno i zapadno pročelje (grafička obrada: I. Tenšek) / Luccari Palace, west and north front (graphic design I. Tenšek)
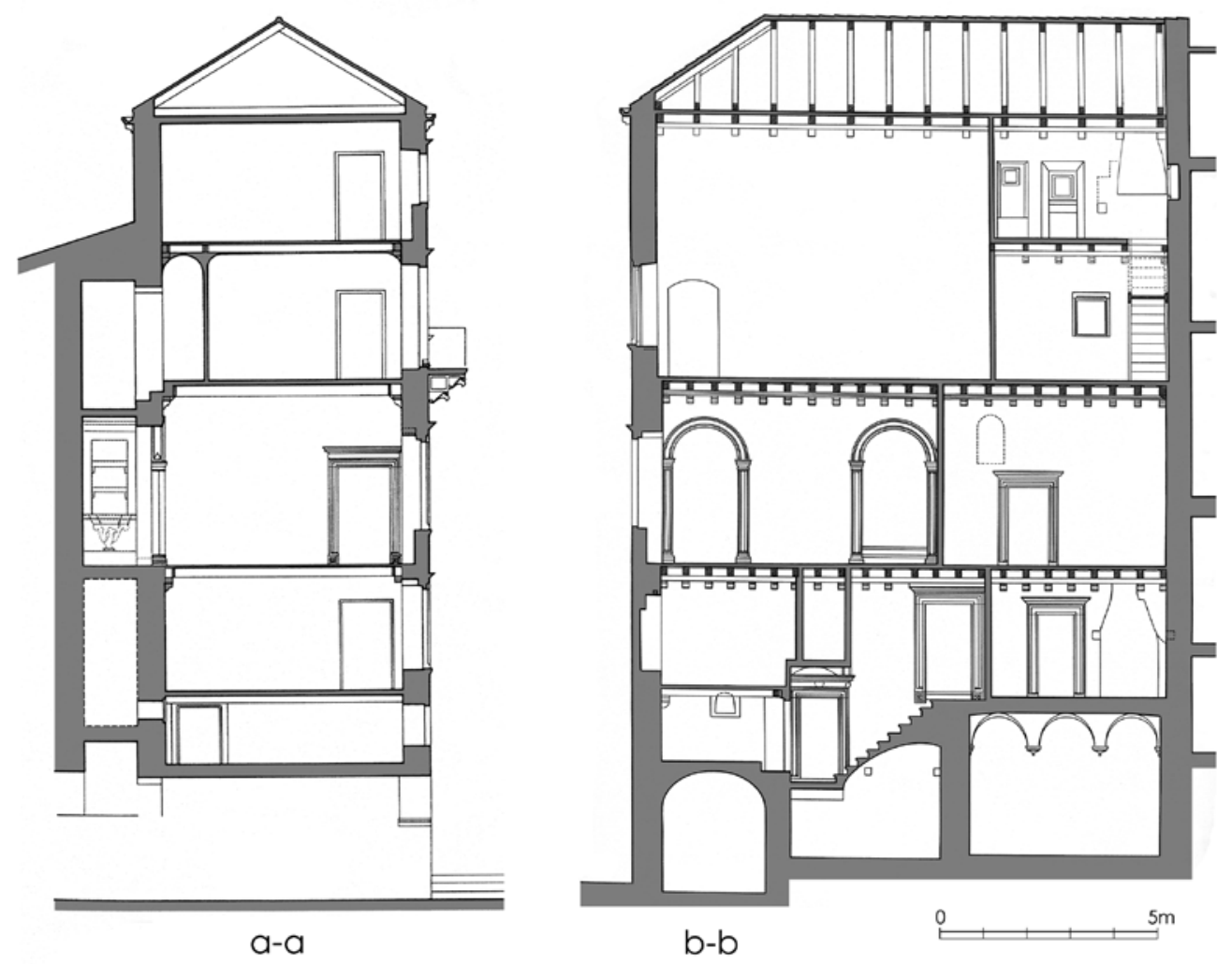

Palača Luccari, poprečni i uzdužni presjek s pogledom na portale stubišta u saloči (grafička obrada: I. Tenšek) / Luccari Palace, transversal section and longitudinal section with a view of the staircase portal in the hall (graphic design I. Tenšek) 


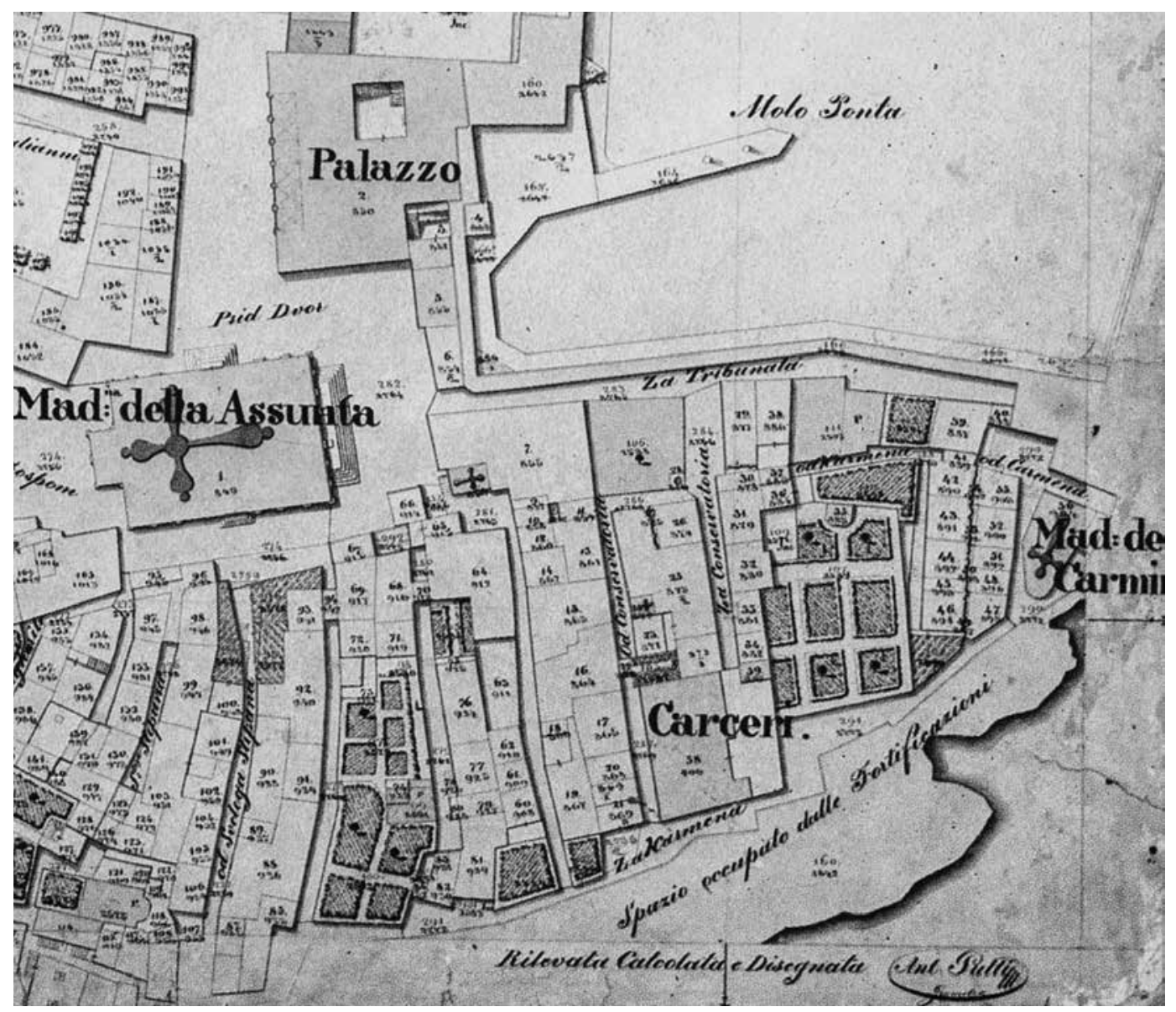

Dubrovnik, katastarska karta iz 1837. godine, Pustijerna s vrtom na lokalitetu Sv. Tome (Državni arhiv u Splitu, Arhiv mapa za Istru i Dalmaciju) / Dubrovnik, land registry map 1837, Pustijerna with a garden in the St Thomas locality (State Archives in Split, Archive of the Maps of Istria and Dalmatia)

nađenom pisanom dokumentacijom, od velike važnosti za upotpunjavanje slike obnove i barokizacije dubrovačke renesansne stambene arhitekture. U tom kontekstu, od posebne je važnosti rano vrijeme njezine obnove, započete svega tri godine nakon potresa, koje joj u određenim elementima daje i prototipsko značenje. ${ }^{25}$

U skladu s takvim okolnostima, relevantna je ponajprije organizacija stubišta, onog elementa u dubrovačkoj reprezentativnoj stambenoj arhitekturi na kojem se temelji stilski i tipološki razvoj, i koji je najbolji pokazatelj je li prostorna organizacija palača nakon potresa temeljena na tradiciji ili je pak okrenuta novim vanjskim poticajima. ${ }^{26} \mathrm{U}$ palači Luccari, dakako, primijenjen je tradicionalni tip jednokrakog stubišta što koristi, kao i prije potresa, prostor dvorane kao podest i vezu između krakova, a nove stilske prohtjeve izražava samo u sceničnoj postavi lučnih portala u dvorani. Slična stubišta nalazimo i u obližnjim barokiziranim gotičkim i renesansnim vlasteoskim rezidencijama, poput palače Sorkočević u Bandurevoj ulici 5, 7 ili palače Ranjina u Ulici braće Andrijića 10, te palača u istoj ulici na kućnim brojevima 2 i 8 od kojih je jedna u to doba vjerojatno pripadala bliskom rođaku nasljednika palače Luccari - Mateju Franjovu Ghetaldiju. ${ }^{27}$ Inovativna rješenja s dvokrakim stubištima organiziranim unutar zasebnih reprezentativno uređenih prostora, koja po svemu sudeći uvode talijanski arhitekti pozivani u državnu službu, učestalije će se početi javljati tek nešto poslije, počam od dokumentima potvrđene gradnje palače Sebastijana Zamanje u Pracatovoj ulici (1672.-1675.). ${ }^{28}$

Jednako je tako decentno i istodobno inovativno vanjsko rješenje obnovljene palače Luccari. Naime, iako je u obnovi palača izgubila na vanjskoj reprezentativnosti sniženjem i smanjenjem otvora glavnog kata, a novi otvori izgledom se usklađuju s onima renesansnim, kako se ne bi narušio integritet pročelja, unutrašnjost se intenzivnije povezuje s okolnim prostorom. U tom pogledu od prvorazredne je važnosti podatak iz 1672. i 1673. godine o oblikovanju otvorenog, vjerojatno ozelenjenog, prostora s paviljonom. Naime, iako je u dosadašnjim istraživanjima graditeljske baštine taj način sanacije u potresu srušenih kuća već valoriziran u širem mediteranskom kontekstu, ${ }^{29}$ ovo je zasada jedno od najranijih pisanih svjedočanstava o intervenciji te vrste u Dubrovniku. 


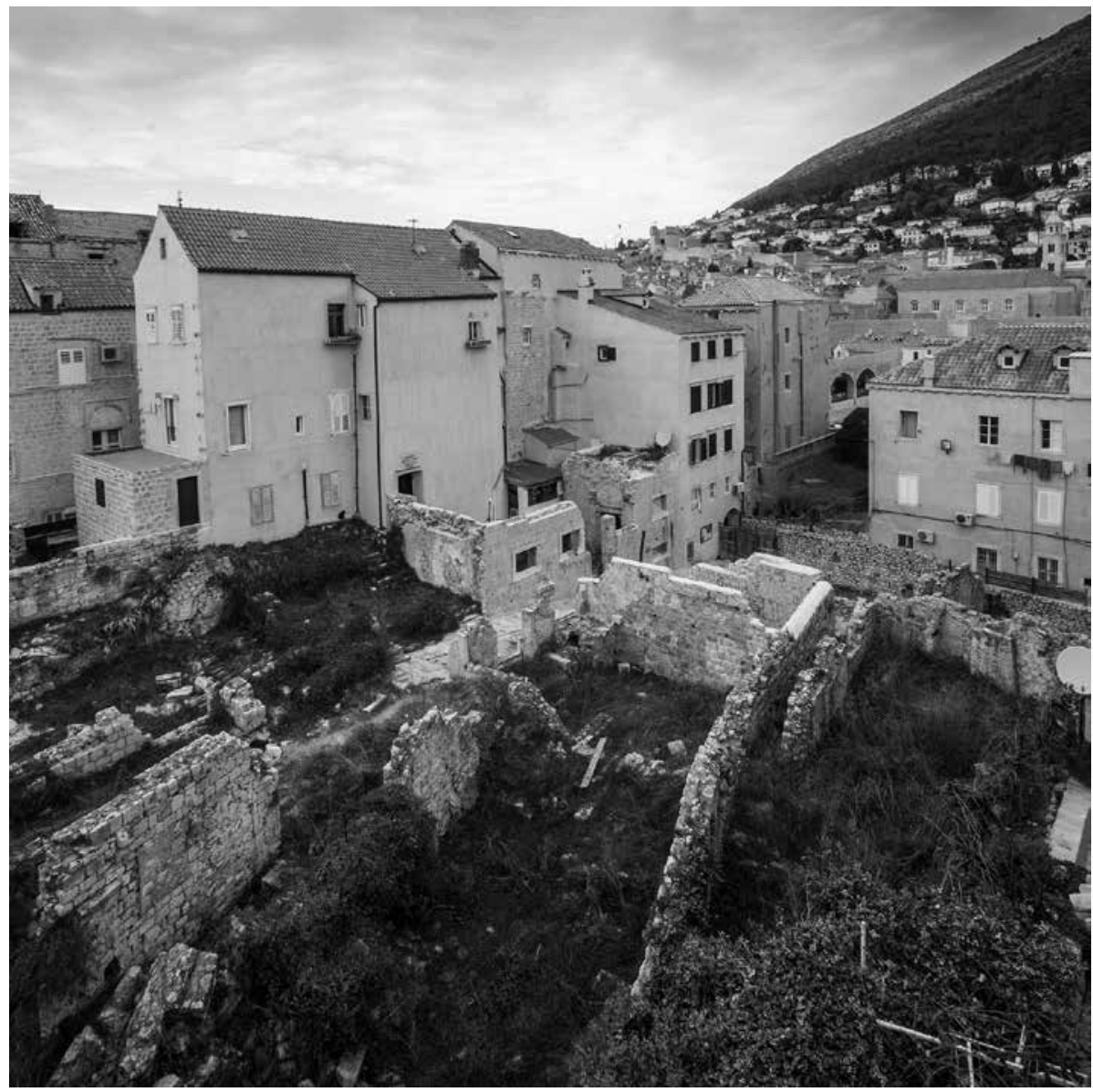

Pustijerna, pogled na začelje palače Luccari i nekadašnji lokalitet Sv. Tome s ostacima arhitekture i ulicama poništenima u potresu 1667. godine (foto: K. Horvat-Levaj) / Pustijerna, view of the back of Luccari Palace and the former Saint Thomas locality, with architectural remains and streets destroyed in the 1667 earthquake

Da je ne samo gradnja kuće nego i formiranje otvorenog prostora uređenog kao vrt mogao biti način da se, u skladu s poznatom odredbom iz 1668. godine, ${ }^{30}$ legalno posvoje tuđe napuštene kuće, pokazuje jedan drugi, novootkriveni dokument ${ }^{31}$ vezan uz obližnju palaču Saraka. Naime, 27. lipnja 1684. plemić Mihovil Antunov Giorgi Bona »daje, ustupa i daruje« plemiću Nikoli Pavlovu Saraki polovicu kuće srušene u potresu, u predjelu Pustijerna, u blizini kuće spomenutog plemića Nikole (zapadna granica joj je ulica Pobijana, a sjeverno i južno Sarakine kuće), uz uvjet da plemić Nikola sam ozida tu polovicu kuće koja je darovana, kako bi sebi napravio vrt, a plemić Mihovil i njegovi potomci mogu je preuzeti kad će htjeti graditi kuću na tom mjestu. Dakle, i ovdje je bila riječ o načinu uređenja vrta nasipavanjem ruševina. Kao i kod rješenja stubišta, napredniji način uređenja neizgrađenih prostora na mjestu srušenih kuća, onaj $s$ izgrađenim nadsvođenim prizemljem u funkciji dućana i terasom na razini prvog kata, javit će se u dubrovačkoj stambenoj arhitekturi nešto kasnije, ${ }^{32}$ također zahvaljujući angažmanu stranih državnih arhitekata na privatnim vlasteoskim gradnjama, kako to ponajprije svjedoči (poslije uništena) terasa palače Bassegli u Ulici Cvijete Zuzorić iz kasnog 17. stoljeća, ${ }^{33}$ o čijoj gradnji su također pronađeni dokumenti. $^{34}$

I na kraju, osim podataka o rješenju unutrašnjeg i vanjskog prostora palače Luccari, spomenuti troškovnik donosi i imena majstora koji su realizirali obnovu. Riječje uglavnom o zidarima i stolarima, domaćim i stranim, a pojedina se imena javljaju i na drugim onodobnim gradnjama. Među njima se ističe zidar Petar Franjov Grankošić (Grancosich), zaposlen na obnovi Kneževa dvora, ali i na brojnim drugim privatnim gradnjama. Da je bila riječ o majstoru u kojeg su poslodavci imali povjerenja govore podaci kako je više puta bio pozivan kao vještak u procjenama vrijednosti obavljenih radova, ili u presudama sporova, ${ }^{35}$ a o Grankošićevu ugledu svjedoči i činjenica da mu je Bratovština zidara iznajmila ruševine svojeg sjedišta u zgradi smještenoj tik uz bratovštinsku crkvu Domino, uz uvjet da je Grankošić obnovi. ${ }^{36}$

U troškovniku palače Luccari nema spomena o nekome voditelju gradnje (proti), a kamoli arhitektu, koji bi, sigurno, da su bili angažirani, povećali trošak gradnje iskazan u troškovniku. To možemo objasniti činjenicom da je bila 
riječ prije svega o popravku, a ne o znatnijem preoblikovanju građevine, što je pak povezano s time da palaču Luccari ne obnavljaju vlasnici za svoj boravak, već dužnost obnove i pravo uživanja rezidencije nasljednici ustupaju onima koji su to u stanju učiniti, tako da palača tijekom desetljeća i pol mijenja korisnike čak u četiri navrata.

Takva situacija, međutim, nije rijetkost u obnovi stambene arhitekture u razdoblju neposredno nakon potresa. Tako primjerice već spomenuti Matej Franjov Ghetaldi za gradnju/obnovu svoje kuće na Pustijerni 1674. godine sklapa ugovor sa zidarom Angelom Lucijem iz Ancone, ${ }^{37}$ a prije spomenuti Nikola Pavlov Saraka proširenje svoje kuće u Sarakinoj ulici na Pustijerni povjerava 1672. godine morlačkim zidarima. ${ }^{38} \mathrm{I} \mathrm{u}$ sporazumima za obnove drugih vlasteoskih kuća javljaju se imena zidara, poput Angela Bianca iz Spoletta. ${ }^{39}$ Kada je međutim riječ o iznimnim investitorima i istaknutim pozicijama, i izvori ali i same građevine svjedoče o projektima znalačkih arhitekata, mahom onih na poziciji državnih arhitekata, koji su vodili obnovu grada nakon potresa. Ovom prilikom izdvajamo, dokumentima potvrđenu, obnovu kuće Luke Zamanje, jednog od glavnih aktera obnove Dubrovnika nakon potresa ${ }^{40}$ smještene nasuprot Kneževu dvoru, za koju vlasnik 1669. godine sklapa ugovor s protomagistrom Ivanom Krstiteljem Raggijem koji je radove trebao izvesti prema projektu rimskog arhitekta Francesca Cortesea, ${ }^{41}$ ili pak gradnju kuće Savina Serafinova Zamagne na južnoj strani Place uz Ulicu sv. Vita (današnja Pracatova), koju su prema nacrtu projektanta gradili spomenuti Petar Grankošić, Angelo Luci i Giuseppe Albici od 1672. do 1673. godine. ${ }^{42}$

Prema tome, novootkrivena dokumentacija o obnovi palače Luccari od 1670. do 1674. godine zorno ocrtava, s više aspekata, kako su se Dubrovčani snalazili da svoje rezidencije i svoj grad vrate u funkciju nakon razornog potresa. No više od toga, preko tih dokumenata spoznata činjenica da njezini vlasnici u doba gradnje nisu bili Kaboge nego Luccari, otvorila je mogućnost novim arhivskim istraživanjima koja su bacila novo svjetlo i na najkvalitetniju građevnu fazu rezidencije - renesansu. O čemu je riječ, može se čitati u novoj monografiji Nade Grujić - Kuća u Gradu, studije o dubrovačkoj stambenoj arhitekturi 15. i 16. stoljeća.

\section{Prilog \\ Dokumenti o obnovi palače Luccari}

Diversa de foris 118, fol. 282r-283v. Die 4 Martii 1684. Mandato Dominorum Consulorum et ad Instantiam ser Matthaei Joannis de Ghetaldi hic infra erit registrata infrascripta Scriptura attento quod regestum eiusdem non reperitur esse registratum prout fuit notatum a ser Natale Garglieni Notario sub infrascripta Scriptura, quae est tenoris sequentis videlicet.

A dí 17 Novembre 1670 in Ragusa. Per la presente scrittura valitura in ogni Giuditio et extra, et come se fosse fatta per mano del publico Cancelliere o Notaro, la quale non si habbia a denuntiare in articulo mortis, ma si possa registrare in ogni tempo, et quando piacerá alla parte. Noi Matteo di Simone Ghettaldi al presente nominato frater Alfonso trovandomi monaco non professo in S. Jacomo, e Francesco di Simone Ghettaldi in nome nostro proprio, e come eredi di quondam ser Francesco de Luccari nostro zio cediamo, et sollenemente concediamo tutta la nostra casa grande posta in Posterna in Mandaglienich Ulizza stata per il passato di ragione di detto quondam ser Francesco de Luccari nostro zio, et a lui pervenuta nella divisione col suo fratello come nelle divisioni --- con li sua stragni, e con tutte le sue raggioni, attinenze, $e$ pertinenze franca et libera d'ogni debito, obligo et angaridio al signor Giovanni di Matteo Ghetaldi nostro zio, con questa conditione, che detto ser Gioanni la debba risarcire, et accomodare, et fare tutti quelli miglioramenti utili, e neccessarii per rendere habitabile la detta casa, la quale quando sará ridotta in stato da potere essere habitata il detto ser Gioanni con li suoi eredi, e successori debbia possedere, godere, et habitare, e fare di quella tutto quello che li piacerá come di cosa propria senza che noi potiamo pretendere in quella nessun attione et questo per anni cinque continui da contarsi dal dí che detta casa sará in stato da poter esser habitata, scorso il qual tempo di anni cinque, e non prima che noi, e li nostri eredi, e successori possiamo senza nessuna oppositione e contraditione pigliare la detta casa, et imposessarsi di quella, con che prima, e non altrimente li dobbiamo pagare quanto dirrá d'haver speso in detta casa rimettendo in sua conscienza, e secondo il conto che ci dará affermandolo con giuramento. Lo accettiamo senza oppositione, e contraditione alcuna qual qual somma del conto delle spese che fará finita la fabrica di detta casa debba registrare in libri publici. Laus Deo.

Con assenso del Illustrissimo et Reverendissimo Signore Pietro Luccari Vescovo di Stagno. Ser Alfonso Basilio di Ghettaldi. Ser Francesco Simone di Ghettaldi.

Die 29 Aprilis 1674. Supradictus ser Franciscus Simeonis de Ghettaldis sponte sua recognovit suprascriptam subscriptionem esse scriptam manu sua propria assensitque registrandi quandocumque. Natalis. Registratum in Diversa de foris de 1674 in fol.185. Natalis.

Die 4 Martii $1684 .{ }^{43}$ Ser Matthaeus Joannis de Ghetaldis filius, et heres dicti quondam ser Joannis sui Patris ad cuius favorem facta extat contrascripta scriptura pro resarcienda et melioranda domo posita hic Ragusii in Pusterna in Mandalienich Ulizza et prout in contrascripta scriptura ad quam dictus sponte sua omnimodam plenariamque potestatem, et facultatem dedit, cessit, et renunciavit, prout dat, cedit et renunciat ser Francisco Sigismundi de Gradis presenti, et acceptanti de 
omnibus, et singulis melioramentis factis in resarcienda et riedificanda dicta domo posita ut supra vigore retroscriptae scripturae et de ipsa scriptura, et prout de tali redificatione ut asseruit patit, ut dictum est supra, omnimodam plenariamque potestatem, et facultatem dedit, cessit, et renunciavit, prout dat, cedit et renunciat ser Francisco Sigismundi de Gradis presenti, et acceptanti suisque heredibus, et successoribus eoque, vel eis cui, seu quibus ius suum deinceps dare, et transferre voluerit stipulanti, et acquirenti domus dictus ser Joannis in locum, et ius suum proprium tam dictorum melioramentorum, quam actionum, et iurium contentorum in contrascripta scriptura eundem quo ad hoc constituens in Procuratorem inevocabilem, veluti in re propria ad plenum cum omni iuris, et facti plenitudine maiori. Et hoc fecit et id circo facere dixit, eo quia statim ac sponte sua contentus et confessus est se habuisse et recepisse a dicto ser Francisco cessionario ducatos quingentum octuaginta quattuor de grossis 40 pro ducato totidem expensos ut asseruit per quondam ser Joannem de Ghetaldi patrem dicti cedentis prout patet per partitos, et computum factum, et factas manu propria dicti quondam ser Joannis quem propterea ser Franciscus eiusque bona omnia heredes, et successores quietavit, et quietat in ampla, valida, opportuna et relevanti forma. Et pro maiori et tutiori cautella dicti ser Francisci de Gradis dictus ser Matthaeus cedens promisit, et convenit dictum ser Franciscum, eiusque heredes, et successores cum bonis suis omnibus manutenere, ac servare indemnem, et indemnem ac penitus sine damno eumque et eos in omni judicio, et extra tueri ac defenderi.

Die 18 Martii 1683. Mandato Dominorum Consulorum et ad eorum instantiam ac pro interesse ser Georgii Secundi de Bucchia Baro riverius retulit se sequestrasse contrascriptam scripturam, ac cessionem eiusdem ita quod usque ad jus cognitum et secundum ordinem. Die 18 Aprilis 1684. Cassus supradictum sequestrum voluntate sequestrantis et sine preiuditio. Die dicta. Mandato Dominorum Consulorum et ad eorum instantiam ac pro interesse ser Matthaei Francisci de Getaldis Giuro riverius retulit se sequestrasse contrascriptam scripturam, ac cessionem eiusdem ita quod usque ad jus cognitum et secundum ordinem. Die 28 Aprilis 1684. Mandato Dominorum Consulorum cassum supradictum sequestrum.

Die 29 Novembris 1685. Ser Franciscus Sigismundi de Gradis cessionarius retroscriptae scripturae, prout in margine eiusdem, sponte sua de retroscripta scriptura sibi cessa ut retro, omnimodam plenariamque potestatem et facultatem dedit, retrocessit et renunciavit, prout dat, retrocedit et renunciat ser Marino Junii de Gradis presenti, et acceptanti cum omnibus, et singulis facultatibus, et aucthoritatibus dicto ser Francisco cessis, et renunciatis prout in retroscripta cessione dicto ser Francisco facta; ponens dictum ser Marinum in locum et ius suum proprium eundemque quo ad hoc constituens in Procuratorem inevocabilem, veluti in rem propriam ad plenum cum omni iuris, et facti plenitudine maiori; quam quidem retrocessionem iuriumque suorum translationem dictus ser
Franciscus fecit, et id circo facere dixit eo quia statim, ac sponte sua contentus, et confessus est se habuisse et recepisse a dicto ser Marino Junii de Gradis ducatos quingentum octuaginta quattuor de grossis 40 pro ducato; pretium retroscriptae cessionis dicto ser Francisco factae, quem propterea ser Marinum dictus ser Franciscus quietavit, et quietat in amplissima quietationis forma, cum hoc tamen pacto inter dictas partes solemni stipulato ne innito, et valato quod presens retrocessio ullo umquam tempore contra dictum ser Franciscum, eiusque heredes, et successores retorqueri non possit.

Die 15 Maii 1687. Ser Franciscus Simeonis de Ghettaldis cui ut asseruit competit ius reddimendi retroscriptae domus sponte sua dat et concedit facultatem et aucthoritatem retroscripto ser Marino Junii de Gradis cessionario eiusdem, ut pro comodanda eandem domo possit expendere in rebus utilibus, et necessariis usque ad ducatos quindecim de grossis 40 pro ducato pro quibus expensis vult, et se contentat stare simplici iuramento dicti ser Marini. Die 17 Maii 1688. Ser Franciscus Simeonis de Ghettaldis accedens in Cancellariam viso per eum computa expensarum factarum in supradicta domo a ser Marino Junii de Gradis in ducatis centum duodecim grossis 28 de grossis 40 pro ducato illud approbavit et ratificavit tamquam bonum et verum, et de assensu ipsius ser Francisci factis, et non solum dictam summam ducatorum 112.28 verum etiam ducatorum quigentum octuaginta quatuor ut supra cessorum eidem ser Marino et factam a quondam ser Joanne Matthaeo de Ghetaldis eius patruo vigore antescriptae scripturae quas expensas in omnibus et per omnia ratificavit et emologavit tamquam veras et sic isto omnique alio meliori modo.

Diversa de foris 119, fol. 1r-14r. Die 8 Martii 1684. Mandato Dominorum Consulorum, et ad instantiam ser Francisci Sigismundi de Gradis hic infra erunt registratae infrascriptae partitae expensarum factarum per quondam ser Joannem de Ghettaldis in melioranda, et redificanda domo posita hic Ragusii in Pusterna in via vocata Mandalienich Ulizza attentis debitis requisitis, quae sunt tenoris sequentis videlicet.

A dí 20 Septembre 1670. Per sbater la casa ducati vinti, et dua barilli di vino valutati a ducati uno il tertiere che fanno ducati 24 grossi 8. A dí 25 Ottobre. Per coppi portati da Vergato cioé migliara dua a ducati 25 il migliaro - ducati 50. A dí 5 Novembre. Per moggia 10 di calcina pigliata da lí-ducati 4. Per somizzar detta ringliesanza in più volte - ducati 25. Per arena d'Isola di Mezzo ducati 2. Per riponirla in stragno grossi 20. A dí 25 sudetto. Per due maestri, e due manoali ducati 1.20. Per render l'arena rinquestata dal Padre fra Domenico Vodopich - 9. Per chiodi delle scale - 12. A dí 26 detto. Per due corde per tirar li scarpelli grossi 16. Per maestri due, e due manoali ducati 1.20. A dí 27 detto. Per maestri due con due manoali ducati 1.20. A dí 28 detto. Per calar i travi scarpeli, et altre cose grossi--- . A dí 29 sudetto. Per maestri due con due manoali ducati 2.20 . 
Die 14 Martii 1680. Mandato Dominorum Consulorum et ad eorum instantiam ac pro interesse ser Georgii Secundi de Bucchia Baro riverius retulit se sequestrasse contrascriptum computum, ita quod usque ad jus cognitum et secundum ordinem. Die 28 Aprilis 1684. Mandato Dominorum Consulorum cassum supradictum sequestrum. ${ }^{44}$

(fol. 1v) A dí 2 Dicembre. Per due muratori con 2 manoali ducati 1.20. Per Spicula marangone con suo garzone grossi 24. Per chiodi grandi ducati 1.20. Per chiodi più piccoli ducati 1.20. Per Jelonzi, e siguimi ---. A dí 5 sudetto. Per Matko Sctarbinich pergiornati tre - 15. A dí 6 Dicembre. Perpiombo grossi 20. A dí 15 sudetto. Per Nicoló muratore con manuali 3 ducati 1.20 con portar li coppi dalla Ponta.

(fol. 2r) A dí 19 corrente. Per Bartolomeo di Andria Giangradovich per sue giornate et assistenza alla fabrica per giorni 20 a grossi 6 il giorno ducati 3. A dí27 Febraro 1671. Per accomodar le porte di Salogia cioé in flibe, e chiodi, e maestro grossi 13. A dí 17 Marzo 1671. Pagati a Cherscia scrivano per coppi 500 pigliati da lui ducati 7.20. A dí sudetto. Per Grancosich per coppi - ducati 5. Per seratura della porta grande ducati 1.20. Per coppi vecchi 160 portati da Breno - 6.20.

(fol. 2v) A dí 2 di Maggio 1682. Per 6 tavole a grossi 4 l'una per accomodar le due finestre, et il tetto sopra la cucina - grossi 24. Per Bartolomeo d'Andrea per giornate 2 - grossi 12. Per due flibbe per portella a grossi 2 - grossi 4. A dí 6 sudetto. Per 4 tavole per comodar la finestra della cucina - grossi 16.

(fol.3r) A dí 23 Maggio. Per servitore di Juan Picetich - grossi 4. A dí 30 sudetto. Per un maestro per accomodar la cappa della cugina - 18. (fol. 3r-3v) A dí 31 Maggio. Per Cruscognia per sbatter la cantonata attaccata alla casa la quale minaccia a cadere-grossi 20.

(fol. 3v) A dí 2 Luglio 1672. Per levar la finestra da casa della parte di Santo Toma a riportarla a loco ducati 1.20.

(fol. 4v) A dí 6 Settembre 1672. Per 4 romasini per due finestre una in Camera, et altra inanzi la Camera in Saloccia ducati 1.6. A dí 7 sudetto. Per accomodar le porte della casa per chiodi rottacorda, et metter contrapeso - grossi 20.

(fol.5r) A dí15 Ottobre 1672. Per Sausovich marangone per accomodar Padiglione - 18. A dísudetto. Per acqua alle donne per rinfrescar la coperta, et in calcina per giorni sei grossi 24 .

(fol. 6v) A dí 12 Novembre 1672. Per Stefano muratore di Gravosa per esser debol maestro - 12. Per Vizkovich di Cattaro per 400 coppi e per chiodi, e tavole per arco del Camarino ducati 2.

(fol.6v-7r) A dí23 sudetto. Per porte della finestra, alla faciata di Ponta comprata con feramento - ducati 2. Al maestro per ponerla, e perfar canale, esbusar il scarpello, et altre bagatelle ocorse - ducato 1.

(fol. 7r) A dí20 di Decembre 1672. Per Stochetta marangone per accomodar il Padiglione - grossi 16.

(fol. 7r) A dí 4 Gennaro 1673. Per detto muratore per far il volto alla finestra grande - grossi 16.

(fol. 8v) A dí primo Fevraro. Per una piastra posta alle porte di fora - 12. Per altra piastra posta alla bocca del scarpello - 6. Per due sglobi grandi per le porte del solaro - 20. A dí 4 suddetto. Per 4 sparanghe per il solaro - 12. Per levar la rovinazza della sala - 8. A dí 19 suddetto. Per due muratori per far la scala - 36. Per muratore per cartegiar la casa - 18.

(fol. 9r) A dí 25 Marzo 1673. Per un muratore per aconciar il tuffo per il volto - 16. A dí 27 sudetto. Per 10 tavole a grossi 4 l'una per forme del volto, e fondamento.

(fol. 9v) A dí 3 Giugno 1673. Per Giorgio Tudesco marangone - grossi 18.

(fol. 10r) A dí 12 sudetto. Per tre tavole per serare la bucaporta in Salocia - 24.

(fol. 10v) A dí 3 Novembre 1673. Per un maestro muratore per metter in calcina li coppi della scala - 18.

(fol. 11r) A dí 25 sudetto. Fatto accordo con Stiepan muratore di Gravosa per ducato uno che debba accomodar alcune baggatelle. A dí 2 Genaro 1674. Per Giorgi Tudesco perli volti - 18. Al maestro muratore per accomodar sopra li volti - 16.

(fol.12r) A dí 12 Genaro 1674. A Giorgio Tudesco marangone - 16. Per 4 mascgli dua femine due romasinetti per poner al fumaro, et alla finestra in aria-30. Per accomodar il Pillo in Salocia sparanghe, maestro, piombo, cola et altro - 1 ducato. A dí 21 sudetto. Per una tavola d’abeto - 24. Per scalini di Podkupglie - 1.20. Per Stefano muratore per imbianchir di novo le machie, et agiustar li mancamenti per tutta settimana agiustai per grossi 30 - 30. A dí 9 Marzo 1674. Per romasino di fora cioé per batitore -

(fol. 12v) A dí 9 Marzo 1674. Per un altro romasino posto di dentro con sua fernetta - 10. A di 10 Marzo. Per un romasino o ver traverso posto alla finestra della cucina - 8. A dí 12 d'Agosto 1677. Per Giuro Tudesco marangone per accomodar lormaro, e la finestra nella cucina per due giornate grossi 32 - 32.

(fol. 13r-14r) A dí 3 di Marzo 1684 Ragusa. Io sottoscritto Matteo di Giovanni Ghetaldi figliolo, et herede do detto Signor Giovanni mio padre affermo con mio giuramento (quatenus opus est etiam in anima del mio quondam signor Padre), $e$ dichiaro che le sudette spese sono realmente state fatte da bona memoria di mio quondam signor padre per risarcire la casa 
posta in Pusterna in Mandalienic Ulizza stata di raggione per il passato di quondam signor Francesco Luccari, e poi pervenuta alli signori Matteo, e Francesco Simone di Ghetaldi, e questo in virtú della scrittura registrata in Diversa de foris de 1682 in fol. 232, et le presenti partite contenute nel presente libro sono scritte di proprio pugno di detto quondam mio padre accendenti in ducati cinquecento, e ottanta quattro grossi 40 salvo veriori calculo, e per fede della veritá mi sono sottoscritto con proprio pugno. Laus Deo. Matteo di Giovanni Ghettaldi affermo ut supra.

Die 4 Martii 1684. Supradictus ser Matthaeus Joannis de Ghettaldis accedens in Cancellariam sponte sua recognovit supradictam declarationem, et subscriptionem factam sub eadem declaratione facta sub partibus contentis in presenti libro esse factam manu sua propria, assensitque registrari quandocumque tam dictam declarationem, quam dictas partitas manu propria quondam ser Joannis sui patris ut asseruit. Et in fidem ego Matthaeus Trifoni publicus hic me subscripsi et quo utor meo solito signo signavi. Laus Deo. Die 8 Martii 1684. Mandato Dominorum Consulorum licentia registrandi attenta recognitione per testes fide dignos. Trifoni.

\section{Dokument o obnovi kuće Mateja Franjova Ghetaldija}

Diversa de foris 109, fol. 250v-251v. Die VI Julii 1674. Ser Matthaeus Ghetaldi quondam Francisci filius ex una, et Magister Angelus Luci murator Anconitanus hic Rhacusii commorans parte ex altera, sponte sua in omni meliori modo, via, jure, ac forma quibus melius, validius, ac magis firmiter de jure dici fieri, atque censeri potest, devenerunt ad infrascriptam conventionem. Videlicet dictus Angelus Luci murator obligans se suaque bona omnia presentia, et futura promisit, et convenit quam primum sua arte et labore, suisque sumptibus et materialibus, id est coppis, calcina, arena, laboratoribus, muratoribusque et aliis ad suam artem pertinentibus, /exceptis matonibus quae necesse essent, quos promisit pro tali effectu dare, et consignare praefatus ser Matthaeus/ perfectionare, et adaptare seu integraliter complere, et perficere facere sua muratoria arte omnes, et singulos deffectus domus praefati ser Matthaei positae in Pusterna in qua ad presens habitat prope ser Georgium Secundi de Buchia. Et versa vice predictus ser Matthaeus obligans se, suaque bona omnia praesentia, et futura pollicitus est, et pollicetur dare, et solvere in pace, et absque ulla contradictione eidem Magistro Angelo pro integra solutione, et satisfactione totius mercedis, materialium, et laborerii predicti ducatos quadraginta de grossis 40 pro ducato. Pro quorum, omnium et singulorum desuper expressorum observatione partes predictae ut supra constitutae obligaverunt se se ad invicem, et hinc inde, cum bonis earum omnibus presentibus, et futuris respective, quia sic inter eas processit ex pacto, isto, ac omni alio meliori modo.

\section{Dokumenti o obnovi kuće Nikole Pavlova Sarake}

Diversa de foris 117, fol.96v-97r. Die XV Maii 1682. Essendo che fu, et é vero che Bosco Vucetin, et Vuko Milutinov Murlachi restarono d'accordo con ser Niccolò Paulo di Saracha di fabricarli dietro la casa nella quale habita al presente esso ser Saracha il circuito di tre stanze con calce e pietra, et havendo esso ser Niccolò sborsato a detti Bosco e Vuko quella somma di denari che fra di loro sono restati di patto, nè havendo essi perfetionato il detto lavoro in conformitá dellobligo, e patto innito col detto ser Niccolò, per tanto hanno pregato detto ser Niccolò che perfetioni il sudetto lavoro con altri maestri a lui ben visti, obligandosi loro di dare e pagare al sudetto ser Saracha tutto ció che lui sborsará agli detti novi maestri per perfetionare il sudetto lavoro in conformitá del patto fra di loro celebrato, e ció ad ogni richiesta di detto ser Saracha, e cosi prommettono, esobligano in questo et in ogni altro miglior modo. Rendendo hoc instrumentum ego Cancellarius stipulavi per verbum mihi transmissum a ser Georgio Garglieni Publico Coadiutore in Cancellaria.

Diversa de foris 119, fol. 51v-52r. Die 27 Junii 1684. Ser Michael Antonii Giorgi Bona sponte, titulo cessionis ac donationis nomine duraturae in perpetuum, dedit, cessit ac donavit, dat, cedit et donat ser Nicolao Pauli de Saraca presenti, et cum grataiura actione acceptanti medietatem seu portionem domus dirutae a maximo terremotu positae in Pusterna prope domum dicti ser Nicolai olim de iure dotali dominae Jacchae matris dicti ser Michaelis cum omnibus juribus, usibus, actionibus et pertinentiis dictae medietatis, cuius domus confines esse dixerunt ab Oriente Viam, ab Occidente Pobianam Ulizam, ab Austro et a Tramuntana domum dicti ser Nicolai, salvis semper verioribus et certioribus si qui sunt confinibus, qui hic sempre pro expressis habeant et intelligantur. Ad habendum, tenendum, gaudendum, utendum, fruendum, perpetuoque possidendum, aliis dandum, vendendum et quomodolibet alienandum ac faciendum omnem et quamcumque dicti ser Nicolai voluntatem tamquam de re propria ad plenum, salvis semper infrascriptis pactis et conditionibus et non aliter nec alio modo. Quam quidem cessionem et donationem dictus ser Michael fecit et facere dixit ob iustas et rationabiles causas animum suum monentes et presertim amoris quo erga ipsum ser Nicolaum prosequitur et prosequutus est. Hac tamen conditione et pacto inter partes predictas concluso quod ipse ser Nicolaus ipsam medietatem domus ut supra donatae ac renunciatae valeat tantum amurari pro faciendo sibi viridarium; et quandocumque ipse ser Michael eiusque heredes et 
successore voluerit et voluerint supra dicta domo fabricare sibi domum quod in arbitrio eiusdem stet reasumere eandem domum absque aliqua solutione melioramentorum per dictum ser Nicolaum faciendorum causa dicti viridarii, quia sic cessit ac donavit. Convenit isto omnique alio meliori modo.

\section{BILJEŠKE}

1 NADA GRUJIĆ, Ladanjska arhitektura dubrovačkog područja, Institut za povijest umjetnosti; Nakladni zavod Matice hrvatske, Zagreb, 1991.; vidjeti bibliografiju u ovom Zborniku.

2 NADA GRUJIĆ, Kuća u Gradu, studije o dubrovačkoj stambenoj arhitekturi 15. i 16. stoljeća, Matica hrvatska, Ogranak, Dubrovnik, 2013.

3 Dubrovnik - Pustijerna. Povijesni razvoj, arhitektonske osobine stambene izgradnje i prijedlozi smjernica za obnovu i revitalizaciju, elaborat Instituta za povijest umjetnosti (autori: Milan Prelog, Nada Grujić, Katarina Horvat, Vladimir Marković, Marija Planić-Lončarić, Biserka Tadić, Ivan Tenšek), Zagreb, 1984., sv. I-IV.

4 Palača Kabužić u Bandurevoj ulici 3, Dubrovnik, elaborat Instituta za povijest umjetnosti i Zavoda za restauriranje umjetnina, autor: Nada Grujić, Zagreb, 1989.

5 NADA GRUJIĆ, IVAN TENŠEK, Domus illorum de Caboga, Radovi Instituta za povijest umjetnosti, 25 (2001.), 101-118.

6 Ibid., 107.

7 Usp. također NADA GRUJIĆ, Dubrovnik - Pustijerna, istraživanje jednog dijela povijesnog tkiva grada, Radovi Instituta za povijest umjetnosti, 10 (1986.), 7-39.

8 Palača Kabužić u Bandurevoj ulici 3, Dubrovnik (bilj. 4), 4.

9 Arhivska istraživanja izvršio je 2003. godine Relja Seferović u okviru projekta Katarine Horvat-Levaj Graditeljska baština Hrvatske od 16. do 18. stoljeća.

10 Državni arhiv u Dubrovniku (dalje: DAD), Diversa de foris, 118, fol. $282 \mathrm{r}-283 \mathrm{v}$.

11 Spominje se 1685. i 1686. kao opat samostana sv. Jakova te vizitator i predsjednik mljetske kongregacije benediktinaca. Ibid., 120, fol. 96 r.

12 Franjo Luccari umro je 1666. godine. Više o njemu u: NENAD VEKARIĆ, Vlastela grada Dubrovnika, sv. 1. Korijeni, struktura i razvoj dubrovačkog plemstva, Hrvatska akademija znanosti i umjetnosti; Zavod za povijesne znanosti u Dubrovniku, Zagreb-Dubrovnik, 2011., 275.

13 Sačuvan je dokument kojim Matej Ivanov Ghetaldi, tada još pod skrbništvom Jurja Secundova Buchie i Mateja Franjova Ghetaldija, koji su također, jedan do drugog imali kuće na Pustijerni (vidjeti bilj. 27), 24. studenoga 1681. daje u najam palaču Luccari Franji Žigmundovu Gradiju. DAD, Diversa de foris, 116, fol. 164v-166r.

14 14. ožujka 1680. općinski službenik Baro zaplijenio je troškovnik "po nalogu gospode konzula« i zbog interesa plemića Jurja Sekundova Bucchie, koji je imao kuću u susjedstvu te bio skrbnik korisnika palače Luccari Mateja Ivanova Ghetaldija (bilj. 13). Nakon što je 3. ožujka 1684. troškovnik potvrdio Matej Ivanov Ghetaldi, 28. travnja prestala je navedena zapljena. Ibid., 119, fol. 1r-14r.

15 Srednjovjekovni obrambeni niz, zvan sub varicos, koji je štitio Pustijernu na strani luke, gubi svoju funkciju nakon izgradnje gradskog zida 1475. godine. LUKŠA BERITIĆ, Utvrđenja grada Dubrovnika, Jugoslavenska akademija znanosti i umjetnosti, Zagreb, 1955.

16 Više o tome u: KATARINA HORVAT-LEVAJ, Problemi interpolacija u nizu sub varicos na Pustijerni, Godišnjak zaštite spomenika kulture Hrvatske, 14-15 (1988.-1989.), 97-109.

17 Primjerice: NADA GRUJIĆ, Reprezentativna stambena arhitektura, Zlatno doba Dubrovnika XV. i XVI. stoljeće, katalog izložbe, Muzejski prostor, Zagreb - Dubrovački muzeji, Dubrovnik, srpanj - rujan 1987., 308; DUŠKO ŽIVANOVIĆ, Vrata i monumentalni portali dubrovačkih kuća i palata, Anali Zavoda za povijesne znanosti Jugoslavenske akademije znanosti i umjetnosti, XXXVI (1988.), 135-173, 169.
18 Vidjeti bilj. 3.

19 Arheološka istraživanja lokaliteta Sv. Toma vodio je 1987. godine arheolog Željko Rapanić.

20 Vidjeti bilj. 4.

21 Uz sjeverni dio začelja palače ostala je sačuvana kuća (Od Pustijerne 6), naknadno spojena s palačom u Bandurevoj 3, dok su uz južni dio njezina istočnog začelja arheološka istraživanja otkrila ostatke monumentalne renesansne palače.

22 Naime, poništen je istočni niz bloka u kojem se nalazi palača Luccari te susjedni istočni dvostruki niz kuća.

23 Dubrovnik - Pustijerna (bilj. 3).

24 Vrt je bio poništen tijekom 20. stoljeća sportskim igralištem. Njegovu organizaciju, zabilježenu na katastarskoj karti iz 1837. (Državni arhiv u Splitu, arhiv mapa), pokazala su arheološka istraživanja (vidjeti bilj. 19). 25 Naime, iako Vijeće umoljenih već 1668. godine donosi odredbe kako bi se privatnici potakli na obnovu kuća, od kojih je najpoznatija ona da svatko može posvojiti tuđu parcelu ako se obveže da će u određenom roku na njoj podići kuću, gradnja privatnih rezidencija tekla je vrlo sporo. LUKŠA BERITIĆ, Urbanistički razvitak Dubrovnika, Zavod za arhitekturu i urbanizam Instituta za likovne umjetnosti Jugoslavenske akademije Znanosti i umjetnosti, Zagreb, 1958., 31.

26 Više o tipologiji stubišta dubrovačkih palača nakon potresa u: KATARINA HORVAT-LEVAJ, Barokne palače u Dubrovniku, Institut za povijest umjetnosti; Zavod za povijesne znanosti Hrvatske akademije znanosti i umjetnosti, Zagreb-Dubrovnik, 2001., 57-99.

27 U dokumentu o obnovi kuće Mateja Franjova Ghetaldija iz 1674. godine spominje se da je smještena u blizini kuće Jurja Secunda Buchie, čijim je grbom obilježena palača u Ulici braće Andrijića 4, 6. DAD, Diversa de foris, 109, fol. 250v-251v.

28 DAD, Acta Consilii Rogatorum, 119, fol. 65. Dokument objavljen u: KATARINA HORVAT-LEVAJ, Građevni razvoj srednjovjekovnoga bloka u povijesnoj jezgri Dubrovnika na primjeru bloka na primjeru bloka omeđena ulicama Od puča, Pracatovom, Između polača i Božidarevićevom, Radovi Instituta za povijest umjetnosti, 16 (1992.), 41-53.

29 VLADIMIR MARKOVIĆ, Kuća i prostor grada u Dubrovniku nakon potresa 1667. godine, Radovi Instituta za povijest umjetnosti, 14 (1990.), 137-149.

30 Vidjeti bilj. 25.

31 DAD, Diversa de foris, 119 , fol. 51v-52r.

32 Više o tome u: VLADIMIR MARKOVIĆ (bilj. 29).

33 KATARINA HORVAT-LEVAJ (bilj. 26), 270-275.

34 Tomo Bassegli dobio je 1685. godine od Orsata Gundulića zemljište u ulici Među Crevljare (današnja Zuzorina) na mjestu dviju srušenih kuća. DAD, Diversa de foris, 119, fo. 206r-v. Njegov sin Marko Bassegli podnosi 9. lipnja 1700. pritužbu na gradnju drvenog mosta koju vrši Lina, udovica pokojnog plemića Luke Vladislavova Gozze na svojoj kući (nekadašnje kazalište) u susjednom bloku južno. Ibid., 131, fol. 211r-v. Usp. također: KATARINA HORVAT-LEVAJ, Urbanistička preobrazba Dubrovnika nakon potresa 1667. godine, Stjepan Gradić, otac domovine, katalog izložbe, (ur.) Pavica Vilać, Dubrovački muzeji, Dubrovnik, 2013., 333-353.

35 Petar Grankošić, Stjepan Radan Blavor i Ivan Petrov posvjedočili su 4. kolovoza 1674. pred predstavnicima Malog vijeća da je plemić Martolica Orsatov Cerva potrošio za zidare i stolare te za građevne materijale za popravak i obnovu kuće smještene u Pustijerni u kojoj sada stanuje, novčani iznos od 700 dukata. DAD, Diversa de foris, 109, fol. 274r-275v. Također i u sporu između kapetana Petra Ohmućevića i Andrije Menessalija oko muri menzalino (polukatni zid) koji se nalazi između njihovih dviju kuća, a podigao ga je Menessali, kao vještaci odabrani su zidari Petar Grankošić i Giuliano di Paolo Rescetin. Ibid., 110, fol. 214, 229.

36 DAD, Libro delle Parti della Confraternità dei Muratori 1669. - 1806., fol. 4r. Grankošić je također i sam iznajmljivao kuće (u Širokoj ulici). DAD, Diversa de foris, 114 , fol. $275 \mathrm{v}$.

37 DAD, Diversa de foris, 109, fol. 250v-251v.

38 Trakt s tri sobe uz stražnju stranu kuće dogradili su Boško Vučetin i Vuko Milutinov. Ibid., 117, fol. 96v-97r. 
39 Ugovor sa zidarom sklopio je 18. listopada 1679. godine plemić Mihovil Antunov Đorđić Bona. Ibid., 114, fol. 271r-272r.

40 Kao predstavnik dubrovačke vlade nakon potresa, Luka Zamagna dopisivao se sa Stjepanom Gradićem u vezi obnove grada i katedrale. Više o tome u: STJEPAN KRASIĆ, Stjepan Gradić: (1613-1683), život i djelo, Jugoslavenska akademija znanosti i umjetnosti, Zagreb, 1987.
41 Dokument objavljen u: KATARINA HORVAT-LEVAJ, Francesco Cortese - projektant palače Zamanja u Dubrovniku (1669.), Peristil, 45 (2002.), 107-122.

42 DAD, Diversa de foris, 108, fol. 246r-249v.

43 Sve što slijedi dopisano je uz tekst, na rubu stranica.

44 Dopisano sa strane na fol. $1 \mathrm{r}$.

Summary

Katarina Horvat-Levaj

Relja Seferović

The Luccari Palace in Pustijerna: The Renewal of the Residential Architecture in Dubrovnik after the Earthquake in 1667

Research of residential architecture is that part of architectural history which must be most skeptical in regard of archive sources. Even when dealing with a city such as Dubrovnik, organized with such social and political acumen and known for its high standards of urban planning, the documents about the owners and builders of residences in the Romanesque and Baroque periods, even when available, very rarely offer researchers the possibility to relate the written data to concrete buildings. Such ambiguous written sources double the effort expected from scholars interested in historical residential architecture, which as a sort of recompense, endows researchers with a special ability to read the material sources, in order to work out the conclusions necessary in making attributions, establishing dates, and evaluating architectural monuments. This special ability graces the work of Professor Nada Grujic, to whom this special issue of Peristil is dedicated with the wish to honour a scholar who has dedicated all her working life to the research of Gothic and Renaissance residential architecture.

In this context Nada Grujic has researched one of the finest Renaissance palaces in Dubrovnik, the Caboga Palace in 3 Bandurova Street in Pustijerna. However, documents about the renovation of the palace after the 1667 earthquake - recently found in the State Archives in Dubrovnik - containing the ruling that the damaged palace will be given to other users who have been entrusted to restore it, as well as the bill of costs for the work performed from 1670 to 1674. The first of the two documents indicate that in the Renaissance period the palace did not belong to the Kaboga family, but to the Luccarifamily (both members of the landed nobility). The mistaken attribution, now corrected, resulted from an erroneous reading of the coats of arms on the palace front. At the same time, the data found in the bill of costs contributed clearly to the notion about the construction history of the palace, formed during research conducted in 1983-1984, archeological digs 1987 and restoration probes made in 1989. Owing to its timely restoration, only three years after the earthquake, the palace did not undergo a radical Baroque transformation, keeping its traditional spatial organization, with a two-part and three-part floor plan distribution, and a staircase placed inside the central channel between the two wings of the block, so that on each floor the main hall is used as a landing and a connecting link between the two wings. The innovation brought by the restoration is the relation of the renovated building to its surrounding, by a newly built solarium with easier access to the garden, which was formed on the remaining rubble, a characteristic way in which the Ragusans got rid of the ruins. The bill of costs also mentions the names of the master builders, some of them, e.g. Petar Grankošić, participating in the restoration of significant public monuments such as the Rector's Palace.

In the context of the complex and protracted process of the restoration of Dubrovnik after the earthquake, the Luccari palace stands out as an exemplary timely restoration, which in some of its segments can represent 
a prototype. Furthermore, its recently found written documentation clearly demonstrates many aspects of the efforts of Dubrovnik citizens to reclaim their residences and their city after the devastating earthquake. Even more, these documents have helped us to realize that during construction this palace was owned by the Luccari, not Kaboga family, and have led researchers to throw a new light on the most valuable Renaissance phase of this building. A study of this phase is published in a new monograph by Nada Grujić A House in the City, Studies of Dubrovnik Fifteenth and Sixteenth Century Houses. 